\title{
Clinical-epidemiological aspects of patients submitted to Percutaneous Coronary Intervention in a university hospital
}

\author{
Aspectos clínico-epidemiológicos de pacientes submetidos à Intervenção Coronária Percutânea em \\ hospital universitário
}

Aspectos clínico-epidemiológicos de pacientes sometidos a la Intervención Coronaria Percutánea en un hospital universitario

\section{Maria Solange Moreira de Lima', Rodrigo Assis Neves Dantas', Neyse Patrícia do Nascimento Mendes', Louise Constância de Melo Alves', Tamara Taynah Medeiros da Silva', Andréa Gomes da Rocha Brito', Daniele Vieira Dantas ${ }^{1}$ \\ ' Universidade Federal do Rio Grande do Norte. Natal, Rio Grande do Norte, Brazil.}

How to cite this article:

Lima MSM, Dantas RAN, Mendes NPN, Alves LCM, Silva TTM, Brito AGR, et al. Clinical-epidemiological aspects of patients submitted to Percutaneous Coronary Intervention in a university hospital. Rev Bras Enferm [Internet]. 2018;71(6):2883-90. DOI: http://dx.doi.org/10.1590/0034-7167-2018-0012

Submission: 01-09-2018 Approval: 03-01-2018

\begin{abstract}
Objective: To outline the clinical-epidemiological profile of patients submitted to Percutaneous Coronary Intervention in a Reference Hospital in Urgent Cardiology Clinic of the state of Rio Grande do Norte. Method: This is a descriptive, exploratory, prospective study with a quantitative approach developed in a Brazilian University Hospital with patients submitted to Percutaneous Coronary Intervention. Data collection occurred between April and October 2017. Results: The sample consisted of 222 patients, of whom $58.10 \%$ underwent Elective Percutaneous Coronary Intervention and $41.89 \%$ were primary, $65.3 \%$ males, with a mean age of 62.7. In comorbidities "Hypertension", "Acute Myocardial Infarction", "Current Smoking" and "Physical Inactivity" were highlighted. Conclusion: In the elective patients, there was a high prevalence of risk factors and in patients with urgent cases, high time of total ischemia. It is necessary to create strategies to structure the care line, to improve the effectiveness of treatment and to minimize adverse outcomes.
\end{abstract}

Descriptors: Cardiovascular Diseases; Myocardial Infarction; Percutaneous Coronary Intervention; Angioplasty; Risk Factors.

\section{RESUMO}

Objetivo: Traçar o perfil clínico-epidemiológico dos pacientes submetidos à Intervenção Coronária Percutânea em um Hospital de referência em urgência cardiológica do estado do Rio Grande do Norte. Método: Trata-se de um estudo descritivo, exploratório, prospectivo, com abordagem quantitativa, desenvolvido em um Hospital Universitário brasileiro com pacientes submetidos à Intervenção Coronária Percutânea. A coleta de dados ocorreu entre abril e outubro de 2017. Resultados: Amostra composta por 222 pacientes, destes, 58,10\% foram submetidos à Intervenção Coronária Percutânea eletiva e 41,89\% à primária, 65,3\% do sexo masculino, com média de idade de 62,7. Nas comorbidades, destacaram-se "Hipertensão Arterial Sistêmica", "Infarto Agudo do Miocárdio Prévio", "Tabagismo Atual" e "Sedentarismo". Conclusão: Nos pacientes eletivos, houve alta prevalência de fatores de risco e nos pacientes da urgência, elevado tempo de isquemia total. Faz-se necessário a criação de estratégias para estruturar a linha de cuidado, melhorar a eficácia do tratamento e minimizar os desfechos adversos.

Descritores: Doenças Cardiovasculares; Infarto do Miocárdio; Intervenção Coronária Percutânea; Angioplastia; Fatores de Risco.

\section{RESUMEN}

Objetivo: Trazar el perfil clínico-epidemiológico de los pacientes sometidos a la Intervención Coronaria Percutánea en un Hospital de referencia en urgencia cardiológica del estado de Rio Grande do Norte. Método: Se trata de un estudio descriptivo, exploratorio, prospectivo con abordaje cuantitativo, desarrollado en un Hospital Universitario brasileño con pacientes sometidos a la Intervención Coronaria Percutánea. La recolección de datos ocurrió entre abril y octubre de 2017. Resultados: La muestra compuesta por 222 pacientes. De esos, 58,10\% fueron sometidos a la Intervención Coronaria Percutánea electiva y el 41,89\% 
a la primaria, el 65,3\% del sexo masculino; la media de edad fue de 62,7. En las comorbilidades, se destacaron Hipertensión Arterial Sistémica, Infarto Agudo de Miocardio previo, tabaquismo actual y sedentarismo. Conclusión: En los pacientes electivos, hubo alta prevalencia de factores de riesgo y en los pacientes de urgencia, elevado tiempo de isquemia total. Se hace necesario la creación de estrategias para estructurar la línea de cuidado, mejorar la eficacia del tratamiento y minimizar los resultados adversos. Descriptores: Enfermedades Cardiovasculares; Infarto de Miocardio; Intervención Coronaria Percutánea; Angioplastia; Factores de Riesgo.

\section{INTRODUCTION}

Cardiovascular Diseases (CVD) are the leading cause of death in Brazil and worldwide. According to the World Health Organization $(\mathrm{WHO})^{(1)}$ in 2015, about eight million people died of ischemic heart disease. In Brazil, from 2004 to 2014, $8.80 \%$ of all deaths were caused by ischemic heart diseases, including Coronary Heart Disease (CHD), which includes Acute Coronary Syndromes. The increasing number of these diseases is an expressive public health problem ${ }^{(2-3)}$.

Acute Coronary Syndromes (ACS) can be understood as an imbalance between supply and consumption of oxygen that can result in myocardial necrosis if there is no immediate intervention. The main etiology of ACS is the rupture of atherosclerotic plaque followed by thrombosis, which may result in partial or total occlusion of a coronary artery ${ }^{(4)}$.

The diagnosis of SCA is based on clinical findings, results of biochemical markers, electrocardiogram analysis, as well as through the Cardiac Catheterization and Coronary Angiography, an invasive diagnostic method that identifies the presence, extent, and severity of coronary atherosclerotic disease. Therefore, the therapeutic approach aims to stabilize the patient and minimize myocardial damage through reperfusion, either through the use of pharmacological therapy with thrombolytics or through invasive treatment through Percutaneous Coronary Intervention $(\mathrm{PCl})^{(4-5)}$.

$\mathrm{PCl}$ is a procedure performed through the insertion of catheters through an arterial access path that has the purpose of remodeling the atherosclerotic plaque and alleviating the stenosis of the vessel. Currently, $\mathrm{PCl}$ associated with stent implantation (metal structures that are positioned in the injured area with the objective of maintaining arterial power and restoring blood flow) is the main form of myocardial revascularization, since $\mathrm{PCl}$ can reestablish coronary flow in about $90 \%$ of patients ${ }^{(4,6)}$.

It is known that the Brazilian population profile has changed in recent years, resulting in an increase in life expectancy and consequently in a relevant increase in the elderly population, which is predominantly more subject to $\mathrm{PCl}$. They are often male, elderly, low schooling, and multiple associated risk factors ${ }^{(7)}$.

The Brazilian Unified Health System (SUS - Sistema Único de Saúde) is responsible for performing about $80 \%$ of $\mathrm{PCl}$ in Brazil and Onofre Lopes University Hospital (HUOL - Hospital Universitário Onofre Lopes), is the only public institution in Rio Grande do Norte State, reference in the care line for patients with acute myocardial infarction ${ }^{(8)}$.

In this context, it is questioned: What are the epidemiological and clinical aspects of the patients submitted to Percutaneous
Coronary Intervention served at a Reference Hospital in Urgent Cardiology Clinic of Rio Grande do Norte State?

In view of the above, the following objectives were elaborated: To outline the epidemiological and clinical profile of the patients submitted to Percutaneous Coronary Intervention in a Reference Hospital in Urgent Cardiology Clinic of Rio Grande do Norte State; To characterize the sociodemographic aspects of patients submitted to Percutaneous Coronary Intervention in an elective and urgent manner; To identify the clinical aspects and associated comorbidities, and describe the outcome of the patient's recovery after $\mathrm{PCI}$.

\section{OBJECTIVE}

To outline the epidemiological and clinical profile of patients submitted to Percutaneous Coronary Intervention in a Reference Hospital in Urgent Cardiology Clinic in Rio Grande do Norte State; To characterize the sociodemographic aspects of patients submitted to Percutaneous Coronary Intervention in an elective and urgent manner; Identify the clinical aspects and associated comorbidities and describe the outcome of the patient regarding their recovery after $\mathrm{PCl}$.

\section{METHOD}

\section{Ethical aspects}

Assuming that the research involved human beings, it followed Resolution 466 of December 12, 2012, of the National Health Council (Conselho Nacional de Saúde)(9). In addition, it was pointed out that prior authorization was obtained from the institution for data collection and the project was approved by the Research Ethics Committee of the Onofre Lopes University Hospital (HUOL - Hospital Universitário Onofre Lopes) of Natal/RN.

\section{Design, place of study and period}

This is a descriptive, exploratory, quantitative approach and prospective data. For the definition of the sample, a simple random sample of probabilistic type was used and for convenience. Based on the number of procedures performed in 2015, the sample was calculated, with a tolerable error of $5 \%$, reaching a sample of 222 patients.

Data were collected between April and October 2017 in the Hemodynamics, Cardiology Unit and Intensive Care Units.

Population or sample; criteria of inclusion and exclusion

The HUOL was selected because it is currently the only public reference institution to meet the demand of patients with 
St-Elevation Myocardial Infarction (STEMI). According to the established flow, after first attendance and diagnosis in institutions that are open door or through the Brazilian Emergency Medical Services (SAMU - Serviço de Atendimento Móvel de Urgência), followed by the initial care that is constituted by the administration of adjuvant therapy and election of the strategy of reperfusion that depends on the availability and experience of each center, the institution contacts the HUOL Hemodynamics sector and performs the regulation, after confirming the diagnosis by the cardiologist-hemodynamicist. Having confirmed the ICU bed from the rear, the patient is referred to perform the Cardiac Catheterization and Coronary Angiography and primary $\mathrm{PCl}$. In addition, HUOL is the largest teaching hospital in the RN and is aimed at training professionals in medicine, dentistry, nutrition, pharmacy, nursing, among other areas ${ }^{(10)}$.

Inclusion criteria were patients older than 18 years and the signing of the Informed Consent Term. Patients who died during the procedure were excluded from the study.

\section{Study protocol}

The data were collected through the computerized and printed medical record, being recorded in a previously prepared tool. The following variables were selected for the analysis: demographic data (event date, gender, schooling, ethnicity, marital status, age, origin, occupation, income); clinical aspects and comorbidities (nature of the event, time of pain, changes in electrocardiogram, medications used in the emergency, hypertension, diabetes, previous history of infarction, previous cerebrovascular accident, previous revascularization surgery, smoking, Physical Inactivity; aspects of the procedure (puncture site, treated coronary arteries, stents used) and evolution aspects (discharge to the ward or discharge to the ICU).

For this study, door-to-balloon time was considered as the time variation between the first contact with a health service and the balloon inflation in the hemodynamic room, as well as the Primary $\mathrm{PCl}$, such as the use of a catheter balloon to reestablish coronary flow, without previous use of fibrinolytics. Regarding adjuvant therapy, the registry of the administration of antiplatelet therapy, antithrombotics, nitrates, analgesia and oxygen therapy was considered ${ }^{(11)}$.

\section{Analysis of results and statistics}

The data were categorized into an Excel spreadsheet and imported into the Statistical Package for the Social Sciences (SPSS) (version 22.0 for Windows), in which they were tabulated and analyzed from descriptive and inferential statistics, and presented in the form of tables.

In the statistical analysis, the significance level of $5 \%$ was used for all statistical tests $(p<0.05)$. To describe the epidemiological profile of patients submitted to $\mathrm{PCl}$, a descriptive analysis of the data was conducted, using central (mean and median) and dispersion (standard deviation) measures for the numerical variables, while the categorical variables were measured by the frequency of occurrences.
The Kolmogorov-Sminorv test was used to evaluate if the numerical variables present a normal distribution and consequently to define the inferential statistics, which indicated an asymmetric distribution of the data $(p<0.05)$. Therefore, the Mann-Whitney test $(U)$ was used to compare the numerical variables of patients submitted to elective and emergency $\mathrm{PCl}$. In addition, Pearson's Chi-square test was used to verify associations between the intervention modalities (urgency and elective) and variables of clinical aspects, comorbidities, risk factors, medication in use, $\mathrm{PCl}$ characteristics and recovery. $\mathrm{X} 2$ ).

\section{RESULTS}

A total of 222 patients were included in the study, of whom $58.10 \%$ underwent Elective Percutaneous Coronary Intervention and $41.89 \%$ were primary $\mathrm{PCl}$. Regarding the origin of the patients, the regulation of Hospitals of all regions of the State prevailed with 85 (38.3\%), followed by Emergency Care Units (UPA - Unidades de Pronto Atendimento), residences of the state capital and residences of the countryside of the State, 68 $(30.6 \%), 37(16.7 \%), 32(14.5 \%)$, respectively.

In Table 1, 65.3\% of the patients were men, the mean age was $62.7( \pm 11.7)$ and the brown population prevailed, with $52.7 \%$ patients. Table 1 and 2 describe the main demographic and socioeconomic characteristics, respectively.

Table 1 - Demographic characteristics of patients submitted to Percutaneous Coronary Intervention, Natal, Rio Grande do Norte, Brazil, 2017

\begin{tabular}{lccc}
\hline & $\begin{array}{c}\text { General sample } \\
(\mathbf{n}=\mathbf{2 2 2})\end{array}$ & $\begin{array}{c}\text { Elective PCI } \\
(\mathbf{n}=\mathbf{1 2 9})\end{array}$ & $\begin{array}{c}\text { Primary PCI } \\
(\mathbf{n}=\mathbf{9 3})\end{array}$ \\
\hline Age (years) Mean $\pm \mathrm{SD}$ & $62.77 \pm 11.78$ & $63.58 \pm 11.30$ & $61.64 \pm 12.39$ \\
Gender & $145(65.3)$ & $85(65.3)$ & $60(64.5)$ \\
$\quad$ Male, $\mathrm{n}(\%)$ & $77(34.7)$ & $44(34.1)$ & $33(35.5)$ \\
Female, $\mathrm{n}(\%)$ & & & \\
Age group & $5(2.3)$ & $3(2.3)$ & $2(2.2)$ \\
$>$ 40 years, $\mathrm{n}(\%)$ & $22(9.9)$ & $9(7.0)$ & $13(14.0)$ \\
$40-50$ years, $\mathrm{n}(\%)$ & $59(26.6)$ & $35(27.1)$ & $24(25.8)$ \\
$50-60$ years, $\mathrm{n}(\%)$ & $72(32.4)$ & $43(33.3)$ & $29(31.2)$ \\
$60-70$ years, $\mathrm{n}(\%)$ & $49(22.1)$ & $32(24.8)$ & $17(18.3)$ \\
$70-80$ years, $\mathrm{n}(\%)$ & $15(6.8)$ & $7(5.4)$ & $8(8.6)$ \\
$\geq 80$ years, $\mathrm{n}(\%)$ & & & \\
Ethnicity & $59(26.6)$ & $38(29.5)$ & $21(22.6)$ \\
White, $\mathrm{n}(\%)$ & $44(19.8)$ & $26(20.2)$ & $18(19.4)$ \\
Black, n $(\%)$ & $117(52.7)$ & $64(49.6)$ & $53(57.0)$ \\
Brown, n $(\%)$ & $2(0.9)$ & $1(0.8)$ & $1(1.1)$ \\
Yellow, n (\%) & & & \\
\hline
\end{tabular}

Note: SD: Standard Deviation; PCI: Percutaneous Coronary Intervention.

It is worth noting the level of schooling (Table 2), where the number of non-literate and incomplete elementary students was $29.7 \%$ and $32 \%$, respectively. $64.0 \%$ were married, $76.6 \%$ had income from one to three minimum wages and $51.8 \%$ were in other occupations/poorly defined. 
Table 2 - Socioeconomic characteristics of patients undergoing Percutaneous Coronary Intervention, Natal, Rio Grande do Norte, Brazil, 2017

\begin{tabular}{|c|c|c|c|}
\hline & $\begin{array}{c}\text { General } \\
\text { sample } \\
(n=222)\end{array}$ & $\begin{array}{c}\text { Elective } \\
\text { PCI } \\
\text { (n=129) }\end{array}$ & $\begin{array}{c}\text { Primary } \\
\text { PCI } \\
(n=93)\end{array}$ \\
\hline \multicolumn{4}{|l|}{ Schooling } \\
\hline Non-literate, n (\%) & $66(29.7)$ & $35(27.1)$ & $31(33.3)$ \\
\hline $1^{\text {st }}$ Incomplete degree, n (\%) & $71(32.0)$ & $45(34.9)$ & $26(28.0)$ \\
\hline $1^{\text {st }}$ Complete degree, $\mathrm{n}(\%)$ & $35(15.8)$ & $20(15.5)$ & $15(16.1)$ \\
\hline $2^{\text {nd }}$ Incomplete degree, $\mathrm{n}(\%)$ & $4(1.8)$ & $2(1.6)$ & $2(2.2)$ \\
\hline $2^{\text {nd }}$ Complete degree, $\mathrm{n}(\%)$ & $37(16.7)$ & $24(18.6)$ & $13(14.0)$ \\
\hline Incomplete higher education, n (\%) & $3(1.4)$ & $1(0.8)$ & $2(2.2)$ \\
\hline Complete higher education, $\mathrm{n}(\%)$ & $6(2.7)$ & $2(1.6)$ & $4(4.3)$ \\
\hline \multicolumn{4}{|l|}{ Marital Status } \\
\hline Single, Widow (er) or Divorced, n (\%) & $80(36.0)$ & $46(35.7)$ & $34(36.6)$ \\
\hline Married, n (\%) & $142(64.0)$ & $83(64.3)$ & $59(63.4)$ \\
\hline \multicolumn{4}{|l|}{ Total income per residence (minimum wage)* } \\
\hline$<1$ minimum wage, $\mathrm{n}(\%)$ & $33(14.9)$ & $21(16.3)$ & $12(12.9)$ \\
\hline 1 - 3 minimum wages, $\mathrm{n}(\%)$ & $170(76.6)$ & $97(75.2)$ & $73(78.5)$ \\
\hline$>3$ minimum wages, $\mathrm{n}(\%)$ & $19(8.6)$ & $11(8.5)$ & $8(8.6)$ \\
\hline \multicolumn{4}{|l|}{ Occupation } \\
\hline Other occupations/ poorly defined, n (\%)** & $115(51.8)$ & $70(54.3)$ & $45(48.4)$ \\
\hline Provision of Services, $\mathrm{n}(\%)$ & $31(14.0)$ & $19(14.7)$ & $12(12.9)$ \\
\hline Agricultural and livestock, extractive plant and animal production, $n(\%)$ & $22(9.9)$ & $10(7.8)$ & $12(12.9)$ \\
\hline Manufacturing Industries and civil construction, $\mathrm{n}(\%)$ & $15(6.8)$ & $7(5.4)$ & $8(8.6)$ \\
\hline Technical, scientific, artistic and similar, n (\%) & $10(4.5)$ & $3(2.3)$ & $7(7.5)$ \\
\hline Trade and assistance activities, $\mathrm{n}(\%)$ & $11(5.0)$ & $9(7.0)$ & $2(2.2)$ \\
\hline Transportation and communication, $\mathrm{n}(\%)$ & $11(5.0)$ & $5(3.9)$ & $6(6.5)$ \\
\hline Administrative, $\mathrm{n}(\%)$ & $5(2.3)$ & $4(3.1)$ & $1(1.1)$ \\
\hline National defense and public safety, n (\%) & $1(0.5)$ & $1(0.8)$ & - \\
\hline Unemployed, n (\%) & $1(0.5)$ & $1(0.8)$ & - \\
\hline
\end{tabular}

Note: $* 937,00 .{ }^{* *}$ Housewives, students, retirees, pensioners, self-employed and sex workers; PCl: Percutaneous Coronary Intervention.

Table 3 - Numerical indicators of the door-to-balloon time related to the electrocardiogram, Natal, Rio Grande do Norte, Brazil, 2017

\section{Primary $\mathrm{PCI}(\mathrm{n}=93)$}

$\begin{array}{lr}\text { Door-to-balloon time } & \\ \quad<90 \text { minutes, } \mathrm{n}(\%) & 11(11.8) \\ 91-360 \text { minutes, } \mathrm{n}(\%) & 24(25.8) \\ 361-720 \text { minutes, } \mathrm{n}(\%) & 40(43.0) \\ >720 \text { minutes, } \mathrm{n}(\%) & 18(19.4) \\ \text { Electrocardiogram } & \\ \text { ECG } w \text { th/ ST, } \mathrm{n}(\%) & 65(69.9) \\ \text { ECG } w \text { th } / \mathrm{ST}+\text { enzymes, } \mathrm{n}(\%) & 28(30.1)\end{array}$

Note: PCI: Percutaneous Coronary Intervention; ECG: electrocardiogram.

All patients regulated by the care line underwent adjuvant therapy. In relation to the door-to-balloon time (Table 3), $11.8 \%$ reached the time less than 90 minutes, being the shortest time, 1 hour and the largest, 48 hours.

The clinical characteristics are summarized in table 4. All the patients presented antecedents, independent of the accomplishment of the $\mathrm{PCl}$ in elective character or urgency. However, only "Hypertension" (HT) comorbidity presented a meaningful association $(\mathrm{p}=$ 0.00) among patients submitted to $\mathrm{PCl}$ on an emergency and elective basis, $68.8 \%$ and $88.4 \%$, respectively. These data, based on the Chance Factor, indicate that the possibility for elective patients to be affected by HT was 3.45 higher than for those submitted to primary $\mathrm{PCI}$.

It was also identified that the "Current Smoking" factor had a marginally meaningful association $(p=$ $0.06)$, and tobacco use was more frequent in patients with urgent cases when compared to the electives (34.4\% vs. $24.0 \%$ ).

Regarding the angiographic characteristics, the type of stent variable had a meaningful association between patients submitted to $\mathrm{PCl}$ on an emergency and elective basis $(p=0.002)$, the conventional one being the most used in emergency procedures $57.0 \%$, while in the electives, pharmacological use $61.2 \%$. In addition, the Chance Factor of an elective patient receiving pharmacological stent is 2.74 times greater than a patient attended on an emergency basis. For this calculation, patients who received stents of both types (Table 5) were excluded.

Regarding the percentage of the lesion, a meaningful difference was identified $(U=1982.5 ; \mathrm{p}=$ 0.00). Patients submitted to emergency $\mathrm{PCl}$ had a meaningfully higher lesion than the elective ones (97.53 versus 89.43). Regarding recovery, we identified an important association between patients submitted to primary and elective $\mathrm{PCl}$, and the recovery modality of these patients $(p=0.00)$, indicating a high effect of association between the outcome and the mode of care (Cramer's $V$ of $0.80, p=0.00$ ). These data indicate that primary $\mathrm{PCl}$ is strongly related to the consequent hospitalization in the Intensive Care Unit (Table 5). 
Table 4 - Clinical characteristics of patients submitted to Percutaneous Coronary Intervention on an elective and urgent basis, Natal, Rio Grande do Norte, Brazil, 2017

\begin{tabular}{|c|c|c|c|}
\hline & $\begin{array}{c}\text { Elective } \\
\text { PCI } \\
(\mathrm{n}=129)\end{array}$ & $\begin{array}{c}\text { Primary } \\
\text { PCI } \\
(\mathbf{n}=93)\end{array}$ & $\begin{array}{c}p \\
\text { value }\end{array}$ \\
\hline \multicolumn{4}{|l|}{ Comorbidities } \\
\hline Hypertension, n (\%) & $114(88.4)$ & $64(68.8)$ & $0.00^{\mathrm{a} . \mathrm{b}}$ \\
\hline Diabetes Mellitus, n (\%) & $50(38.8)$ & $35(37.6)$ & $0.489^{b}$ \\
\hline Acute Myocardial Infarction, n (\%) & $71(55.0)$ & $20(21.5)$ & $0.00^{\mathrm{a} . \mathrm{b}}$ \\
\hline Coronary Artery Bypass Surgery, n (\%) (anterior), n (\%) & $5(3.9)$ & $0(0.0)$ & $0.064^{b}$ \\
\hline Stroke, $\mathrm{n}(\%)$ & $8(6.2)$ & $7(7.5)$ & $0.789^{b}$ \\
\hline BMI of adult patients & & & $0.248^{b}$ \\
\hline Overweight, n (\%) & $19(40.4)$ & $19(48.7)$ & \\
\hline Obesity, n (\%) & $9(19.2)$ & $8(20.5)$ & \\
\hline BMI of elderly patients & & & $0.575^{\mathrm{b}}$ \\
\hline Overweight (levels 1, 2 and 3), n (\%) & $34(41.5)$ & $23(42.6)$ & \\
\hline Family History, n (\%) & $47(36.4)$ & $38(40.9)$ & $0.298^{b}$ \\
\hline \multicolumn{4}{|l|}{ Life Habits } \\
\hline Alcoholism, n (\%) & $29(22.5)$ & $19(20.4)$ & $0.422^{b}$ \\
\hline Current Smoking, n (\%) & $31(24.0)$ & $32(34.4)$ & $0.06^{\mathrm{b}}$ \\
\hline Previous Smoking, n (\%) & $35(27.1)$ & $23(24.7)$ & $0.404^{b}$ \\
\hline Physical Inactivity, n (\%) & $119(92.2)$ & $83(89.2)$ & $0.295^{\mathrm{b}}$ \\
\hline Physical Activity, n (\%) & $10(7.8)$ & $10(10.8)$ & $0.295^{b}$ \\
\hline
\end{tabular}

Note: ${ }^{a} p<0.05 ;{ }^{b} p$-value for Pearson's Chi-square; PCI: Percutaneous Coronary Intervention.

Table 5 - Angiographic and procedure characteristics, Natal, Rio Grande do Norte, Brazil, 2017

\begin{tabular}{|c|c|c|c|}
\hline & $\begin{array}{l}\text { Elective PCI } \\
(\mathrm{n}=129)\end{array}$ & $\begin{array}{c}\text { Primary PCI } \\
(\mathbf{n}=93)\end{array}$ & $\begin{array}{c}p \\
\text { value }\end{array}$ \\
\hline Stents & & & $0.00^{a . b}$ \\
\hline Conventional, n (\%) & $43(33.3)$ & $53(57.0)$ & \\
\hline Pharmacological, n (\%) & $79(61.2)$ & $36(38.7)$ & \\
\hline Conventional and pharmacological, $\mathrm{n}(\%)$ & $7(5.4)$ & $4(4.3)$ & \\
\hline Number of Stents & & & $0.33^{\mathrm{b}}$ \\
\hline One, n (\%) & $86(66.7)$ & $54(58.0)$ & \\
\hline Two, n (\%) & $30(23.3)$ & $30(32.3)$ & \\
\hline Three or more, $\mathrm{n}(\%)$ & $13(10.0)$ & $9(9.7)$ & \\
\hline Coronary artery treated & & & $0.26^{\mathrm{b}}$ \\
\hline Right Coronary Artery, n (\%) & $38(29.5)$ & $28(30.1)$ & \\
\hline Circumflex Artery, n (\%) & $13(10.1)$ & $12(12.9)$ & \\
\hline Mid Left Anterior Descending Artery, n (\%) & 47 (36.4) & 39 (41.9) & \\
\hline Others $\mathrm{n}(\%)$ & $12(9.3)$ & $2(2.2)$ & \\
\hline More than one treated, $\mathrm{n}(\%)$ & 19 (14.7) & $12(12.9)$ & \\
\hline Punction site & & & $0.10^{\mathrm{b}}$ \\
\hline Radial & $41(32.0)$ & 38 (40.9) & \\
\hline Femoral & $83(64.8)$ & $55(59.1)$ & \\
\hline Brachial & $4(3.1)$ & $0(0.0)$ & \\
\hline Percentage of injury (mean \pm SD) & $89.43 \pm 9.57$ & $97.53 \pm 6.02$ & $0.00^{\mathrm{a} . \mathrm{c}}$ \\
\hline Complications, n (\%) & $8(6.2)$ & $8(8.6)$ & $0.33^{\mathrm{b}}$ \\
\hline Recovery & & & $0.00^{\mathrm{a} . \mathrm{b}}$ \\
\hline Nursing, n (\%) & $106(82.2)$ & $0(0.0)$ & \\
\hline Intensive Care Unit, $\mathrm{n}(\%)$ & $23(17.8)$ & $93(100.0)$ & \\
\hline
\end{tabular}

Note: Own research; $p<0.05$; $b$ p-value for Pearson's Chi-square; cp-value for the Mann-Whitney test; SD: Standard Deviation; PCl: Percutaneous Coronary Intervention.

\section{DISCUSSION}

In this study, male patients prevailed $(65.3 \%)$. As for females, the percentage of $34.7 \%$ of the total sample was found. Of these, $93.6 \%$ were older than 50 years. Analyzes conducted in the UK with 1,271 patients found that $79.5 \%$ were males and $20.5 \%$ females, in view of this, the comparative study shows that $48.1 \%$ of the female population had age group over 70 years, whereas in men this percentage was only $28.6 \%^{(12)}$.

Thus, research indicates that cardiovascular events in women have a lower incidence, probably due to the protective function of estradiol. However, the sudden decrease in estrogen levels in the postmenopausal period is associated with a high cardiovascular risk ${ }^{(13)}$.

In the population of this study, low education and income, marital status, brown and in relation to the profession predominated, $51.8 \%$ were among other occupations/poorly defined. Research performed at a Hospital in the Northwest Region of Rio Grande do Sul State also showed low schooling, since $72.9 \%$ had incomplete elementary school and $6.3 \%$ were not literate. In addition, the same study stated that $58.3 \%$ receive less than $3 \mathrm{mini}-$ mum wages per month, $70.8 \%$ were married, $37.5 \%$ retired and $83.3 \%$ are white ${ }^{(13)}$.

According to the Brazilian Institute of Geography and Statistics (IBGE - Instituto Brasileiro de Geografia e Estatística) ${ }^{(14)}$, the year 2016 showed that in the northeast of Brazil, approximately $26.4 \%$ of the population is white and $73 \%$ are blacks, while in the percentage of black-and-white-brown can reach $76.7 \%$ and $22.5 \%$, respectively.

These divergences in the ethnicity/color indicator are possibly due to the regional difference in the surveys. Low socioeconomic 
conditions are related to the increased risk of Cardiovascular Diseases. In addition, studies indicate that Hypertension, Diabetes Mellitus, Smoking, Obesity and Alcoholism are more frequent in individuals of lower socioeconomic level, and schooling is one of the indicators of socioeconomic level that more satisfactorily correlates with the periodicity and intensity of risk factors cardiovascular ${ }^{(15)}$.

The deluge for the effectiveness of reperfusion therapy in St-Elevation Myocardial Infarction is shown as an unfavorable prognostic predictor. In this study, it was observed that door-to-balloon time for $\mathrm{PCl}$ was extensive; countering what is considered the current Brazilian guideline for the treatment of St-Elevation Myocardial Infarction, in which the ideal doorto-balloon time should be less than 90 minutes. Such data can be justified due to the existence of only one center to meet all state demand, as well as the absence of care protocols, delay in diagnosis and little articulation between the various points of the care network ${ }^{(11,16)}$.

In this study, a door-to-balloon time between 360-720 minutes prevailed $(40 \%)$. Comparing with a study carried out in Southeast Asia with 1,268 patients, in which $16 \%$ had a 120 minute balloon port delay ${ }^{(17)}$. Such research has shown that the main causes of delay were the delay in emergency service, atypical clinical presentation and unstable condition requiring stabilization, also affirming that these delays are the major causes of death.

Research in databases has shown that strategies for reducing door-to-balloon time are still performed in isolation, among the strategies, is the electrocardiogram in the prehospital care, early activation of the hemodynamic service and multiprofessional communication in the process of Percutaneous Coronary Intervention. In the city of Belo Horizonte/MG, a meaningful reduction $(12.3 \%$ to $7.1 \%)$ in the mortality rate was observed, after the implantation of the AMI care line, with the integration of services, training for the professionals involved ${ }^{(18-19)}$.

With respect to the comorbidities presented by the patients in the present study, there was prevalence of Arterial Hypertension followed by Diabetes Mellitus. Corroborating our results, which showed a higher incidence of hypertension in women $(88.3 \%)$ than in men $(75.9 \%)$, an analysis of 2,426 patients in hospitals in South-East Asia demonstrated the prevalence of hypertension in $81.4 \%$ in women and $57.3 \%$ in men, and in Diabetes Mellitus in $65.6 \%$ of women and $43.6 \%$ in men ${ }^{(20)}$.

Table 4 shows that the highest prevalence of previous Acute Myocardial Infarction (AMI) was in elective patients. A study (21) performed with 586 patients submitted to primary $\mathrm{PCI}$, only $5.8 \%$ presented such comorbidity, being one of the factors responsible for possible $\mathrm{PCI}$ death. A national study developed in the United Kingdom pointed out that of 1,271 patients submitted to $\mathrm{PCl}$, $54.5 \%$ between men and women already had previous $\mathrm{MI}^{(12)}$.

As for the previous Coronary Artery Bypass Surgery (CABS), a prevalence of only $3.9 \%$ was observed in elective patients in the study population. Analysis of 5,664 patients from an Iranian Hospital showed that only $4 \%$ had undergone surgery ${ }^{(22)}$. In the city of Porto Alegre/RS, 4\% of 1,108 patients from the survey had this history of $\mathrm{CABS}^{(23)}$.

Regarding Stroke, the percentage found in this study $(6.7 \%)$ among elective and patients with urgent cases was higher than in other studies, which indicated percentages from $3.3 \%$ to $4.7 \%{ }^{(12,19,24)}$.

A survey conducted in a city of São Paulo State with 489 patients showed that $35.5 \%$ were overweight ${ }^{(24)}$. Studies in Iran and Germany also showed that overweight was predominant in the patients analyzed ${ }^{(22,25)}$. Another study conducted in Kuala Lumpur and Malaysia showed that of 28,472 patients analyzed, $43.8 \%$ were overweight and $36.6 \%$ were obese ${ }^{(26)}$. A survey conducted in several hospitals in Japan showed that of 10,142 patients analyzed, 30.5\% were overweight and $6.2 \%$ were obese ${ }^{(27)}$. Similarly, Table 4 of this study shows that a meaningful number of adult patients were overweight and an important amount of obesity was observed in the elderly.

Family history is one more factor contributing to the manifestation of Cardiovascular Diseases, and in this study, there were a considerable number of patients with such comorbidity. Some authors confirm this data, revealing meaningful numbers of patients with Family History ${ }^{(12,21-22,24,26)}$

In the current study, Current Smoking is a relevant data, being one of the most present risk factors in patients with Cardiovascular Diseases, as it leads to an imbalance of prothrombotic antithrombotic factors ${ }^{(25)}$. In the study in Bosnia and Herzegovina, of the 586 patients in the study, $64.7 \%$ smoked $^{(21)}$. In the United Kingdom, of $1,271,65.4 \%$ are smokers ${ }^{(12)}$. Many other studies have shown that a large proportion of patients undergoing $\mathrm{PCl}$ are active smokers ${ }^{(13,16,22-24)}$. In the same way that the current smoker is more predisposed to having Cardiovascular Diseases, the former smoker is also a risk factor to be considered ${ }^{(15)}$. Considering this, we observed in Table 4 considerable percentages in both elective and emergency patients, respectively $27.1 \%$ and $24.7 \%$.

It can be observed in the results that $99.9 \%$ of the total number of patients was physically inactive. Therefore, studies ${ }^{(13)}$ conducted confirm that the number of physically inactive patients in $\mathrm{PCl}$ is high, with $91.7 \%$ of the 48 patients analyzed. In addition, an analysis performed in the Northern region of Paraná State showed that $52.5 \%$ of patients submitted to $\mathrm{PCl}$ were physically inactive ${ }^{(28)}$. Another study indicated that $71 \%$ of patients who underwent coronary angioplasty had Physical Inactivity ${ }^{(29)}$.

A Brazilian study ${ }^{(24)}$ with 489 patients submitted to $\mathrm{PCl}$ in the city of Marília, SP, showed a higher prevalence in the use of conventional stents $(98.6 \%)$, contrary to what was found in the present study, which indicates greater use of stents of the pharmacological type when compared to the number of elective patients $(61.2 \%)$. However, in relation to patients with urgent cases, it is still observed the predominant use of conventional stents (57\%).

Analysis of 5,664 patients performed in Tehran, the main city of the Islamic Republic of Iran, the number of "one" stents predominated $(71.3 \%)^{(22)}$. These data corroborate with those found in Table 5, where the majority of elective and emergency patients received a stent. In relation to the treated coronary, the Mid Left Anterior Descending Artery (elective and urgency), followed by the Right Coronary Artery, predominated. Studies have confirmed that the most commonly treated coronary artery in patients performing $\mathrm{PCl}$ is the Mid Left Anterior Descending Artery and secondly the Right Coronary Artery(21-24).

The femoral artery was the most commonly used puncture site (Table 5), followed by the radial one. According to research done in Rio Grande do Sul State, the femoral route was more 
prevalent. However, a survey conducted in Bosnia and Herzegovina and another one conducted in the city of Marília - SP, the radial route predominated, respectively $70.8 \%$ and $94.3 \%{ }^{(23-24)}$. Analysis performed in the United States has shown that the radial approach is safer than the femoral approach, since they are less likely to cause complications, such as hemorrhage, hematoma formation, thrombophlebitis, ecchymosis and pseudoaneurysm ${ }^{(30)}$.

\section{Study limitations}

This study has limitations because it is observational, unicentric and has a limited sample. In relation to the times used, the possibility of bias is admitted, since they were obtained through the records in medical records.

Contributions to the sectors of Nursing, Health or Public Policy It is believed that papers of this nature can contribute, in particular, to the creation of strategies aimed at the prevention of these diseases, as well as collaborate in the formulation of health policies aimed at strengthening the quality of care offered, as well as to enable the implementation of the line of care that allows harm reduction, through the training of professionals and integration of services.

\section{CONCLUSION}

It is observed that there is a predominance of men, elderly, brown, married, with low level of education. Regarding the origin, the hospitals originated in all regions of the State, followed by the Emergency Care Units (Unidades de Pronto Atendimento), located in the metropolitan region. Individuals who underwent elective $\mathrm{PCl}$ had a high prevalence of risk factors and those who underwent $\mathrm{PCI}$ had a high time of ischemia. It is believed that the creation of strategies aimed at the prevention of these diseases, as well as the formulation of health policies that contemplate the structuring of the care line in the state and the strengthening of the quality of care offered through the integration of the various services of the network are to reduce future events, minimize adverse outcomes, and improve treatment efficacy.

\section{REFERENCES}

1. Organização Mundial da Saúde-OMS. The top 10 causes of death[Internet]. 2017[cited 2017 Dec 07]. Available from: http://www. who.int/mediacentre/factsheets/fs310/en/

2. Brasil. Ministério da Saúde. Plano Nacional de Saúde PNS 2016-2019[Internet]. 2016[cited 2016 Sep 03]. Available from: http:// conselho.saude.gov.br/ultimas noticias/2016/docs/PlanoNacionalSaude 2016 2019.pdf

3. Issa AFC, Oliveira GMM, Abreu LM, Rocha RM, Esporcatte R. MAC: Manual de Atualização e Conduta : Síndrome Coronariana Aguda (SCA). Rio de Janeiro: Planmark; 2015.

4. Guimarães HP, Lopes RD, Zazula AD, Berwanger O. Guia Prático de Síndromes Coronárias Agudas. São Paulo: Atheneu; 2013.

5. Araújo DF, Araújo ERM, Silva MRV, Silva NC, Guimarães MSO, Amorim Neta FL. Perfil clínico e epidemiológico de pacientes com síndrome coronariana aguda. Rev Enferm UFPI[Internet]. 2014[cited 2016 Sep 03];2(3):78-84. Available from: http://www. ojs.ufpi.br/index.php/reufpi/article/view/1895/pdf

6. Kuhn OT, Bueno JFB, Loro MM, Kolankiewicz ACB, Rosanelli CLSP, Winkelmann ER. Perfil de pacientes submetidos a cateterismo cardíaco e angioplastia em um Hospital Geral. Rev Contexto Saúde[Internet]. 2015[cited 2016 Sep 08]; 15(29):4-14. Available from: http://oaji.net/articles/2017/1006-1500641756.pdf

7. Ferreira AG, Coelho Filho CD, Lourenço RA, Esporcatte R. A doença arterial coronariana e o envelhecimento populacional: como enfrentar esse desafio? Med HUPE-UERJ[Internet]. 2013[cited 2017 Jan 01];12(supl1):13-24. Available from: http://revista.hupe. uerj.br/detalhe_artigo.asp?id $=402$

8. Piegas LS, Haddad N. Intervenção coronariana percutânea no Brasil: resultados do Sistema Único de Saúde. Arq Bras Cardiol[Internet]. 2011 [cited 2016 Oct 30];96(4):317-24. Available from: http://www.scielo.br/pdf/abc/v96n4/en_aop02511.pdf

9. Brasil. Conselho Nacional de Saúde. Resolução n 466, de 12 de dezembro de 2012. Aprova diretrizes e normas regulamentadoras de pesquisas envolvendo seres humanos[Internet]. Diário Oficial[da] República Federativa do Brasil. 12 de dezembro, 2012[cited 2015 Apr 15]. Available from: http://bvsms.saude.gov.br/bvs/saudelegis/cns/2013/res0466_12_12_2012.html

10. Hospital Universitário Onofre Lopes-HUOL. Infraestrutura[Internet]. Rio Grande do Norte. 2016[cited 2016 Sep 18]. Available from: http://www.ebserh.gov.br/web/huol-ufrn/infraestrutura

11. Piegas LS, Timerman A, Feitosa GS, Nicolau JC, Mattos LAP, Andrade MD, et al. V Diretriz da Sociedade Brasileira de Cardiologia sobre Tratamento do Infarto Agudo do Miocárdio com Supradesnível do Segmento ST. Arq Bras Cardiol[Internet]. 2015[cited 2017 Nov 25];105(2):1-105. Available from: http://publicacoes.cardiol.br/2014/diretrizes/2015/02_TRATAMENTO $\% 20$ DO $\% 20 I A M \% 20$ COM $\% 20$ SUPRADESNIVEL $\% 20 D O \% 20$ SEGMENTO $\% 20$ TT.pdf

12. Sharma V, Wilson W, Smith W, McEntergart M, Oldroyd K, Sidik N, et al. Comparison of characteristics and complications in men versus women undergoing chronic total occlusion percutaneous intervention. Am J Cardiol[Internet]. 2016[cited 2017 Dec 02];119:535-41. Available from: https://www.ncbi.nlm.nih.gov/pubmed/27923460

13. Mertins SM, Kolankiewicz ACB, Rosanelli CLSP, Loro MM, Poli G, Winkelmann ER, et al. Prevalência de fatores de risco em pacientes com infarto agudo do miocárdio. Av Enferm[Internet]. 2016[cited 2017 Dec 02];34(1):30-8. Available from: http://www. 
scielo.org.co/pdf/aven/v34n1/v34n1a04.pdf

14. Brasil. Instituto Brasileiro de Geografia e Estatística-IBGE. Síntese de Indicadores Sociais - SIS[Internet]. 2016 [cited 2017 Dec 04]. Available from: https://www.ibge.gov.br/estatisticas-novoportal/multidominio/genero/9221-sintese-de-indicadores-sociais. html?\&t= downloads

15. Martin RSS, Franco RJS, Martin AS. Influência do nível socioeconômico sobre os fatores de risco cardiovascular. J Bras Med[Internet]. 2014[cited 2017 Dec 01];102(2):34-7. Available from: http://files.bvs.br/upload/S/0047-2077/2014/v102n2/a4193.pdf

16. Barbosa RR, Cesar FB, Serpa RG, Bayerl DMR, Mauro VF, Veloso WUG, et al. Results of primary percutaneous coronary intervention according to the total ischemic time. Rev Bras Cardiol Invasiva[Internet]. 2014[cited 2017 Nov 29];22(2):137-42. Available from: http://www.scielo.br/pdf/rbci/v22n2/en_0104-1843-rbci-22-02-0137.pdf

17. Sim WJ, Ang AS, Tan MC, Xiang WW, Foo D, Loh KK, et al. Causes of delay in door-to-balloon time in South-East Asian patients undergoing primary percutaneous coronary intervention. PLoS One[Internet]. 2017[cited 2017 Dec 01];12(9):e0185186. Available from: https://www.ncbi.nlm.nih.gov/pubmed/28934306

18. Pinto LLN, Corrêa AR, Donoso MTV, Matos SS, Manzo BF. Estratégias para reduzir o tempo porta-balão nos pacientes com infarto agudo do miocárdio. Rev Min Enferm[Internet]. 2016[cited 2018 Feb 18];20:e954(1):1-10. Available from: http://www.reme.org. br/artigo/detalhes/1088

19. Marcolino MS, Brant LCC, Araujo JG, Nascimento BR, Castro LRA, Martins P, et al. Implantação da Linha de Cuidado do Infarto Agudo do Miocárdio no Município de Belo Horizonte. Arq Bras Cardiol[Internet]. 2012[cited 2017 Nov 27];8(5):327-45. Available from: http://www.scielo.br/pdf/abc/2013nahead/aop5145.pdf

20. Jarrah MI, Hammoudeh AJ, Al-Natour DB, Khader YS, Tabbalat RA, Alhaddad IA, et al. Gender differences in risk profile and outcome of Middle Eastern patients undergoing percutaneous coronary intervention. Saudi Med J[Internet]. 2017[cited 2017 Dec 05];38(2):149-55. Available from: https://www.ncbi.nlm.nih.gov/pmc/articles/PMC5329626/

21. Jahic E. Experience and outcomes of primary percutaneous coronary intervention for patients with ST-Segment Elevation Myocardial Infarction of Tertiary Care Center in Bosnia and Herzegovina. Med Arch[Internet]. 2017[cited 2017 Dec 02];71(3):183-7. Available from: https://www.ncbi.nlm.nih.gov/pubmed/28974830

22. Ghoreyshi-Hefzabad SM, Kassaian SE, Kheirkhah-Sabetghadam S, Jalali A, Poorhosseini H, Movahed MR, et al. Impact of sex on long-term clinical outcomes after percutaneous coronary intervention. Crit Pathw Cardiol[Internet]. 2017 [cited 2017 Dec 01];16(4):161-6. Available from: https://www.ncbi.nlm.nih.gov/pubmed/29135625

23. Cardoso CO, Lana DD, Bess G, Sebben JC, Mattos E, Baldissera FA, et al. Resultados das intervenções coronárias percutâneas primárias realizadas nos horários diurno e noturno. Rev Bras Cardiol Invasiva[Internet]. 2014[cited 2017 Nov 30];22(1):10-5. Available from: http://www.scielo.br/pdf/rbci/v22n1/0104-1843-rbci-22-01-0010.pdf

24. Andrade PB, Rinaldi FS, Bienert IRC, Barbosa RA, Bergonso MH, Matos MPB, et al. Perfil clínico e angiográfico de pacientes jovens submetidos à intervenção coronária percutânea primária. Rev Bras Cardiol Invasiva[Internet]. 2015[cited 2017 Dec 01];23(2):91-5. Available from: https://www.sciencedirect.com/science/article/pii/S0104184315000375

25. Reinstadler SJ, Eitel C, Fuernau G, Waha S, Desch S, Mende M, et al. Association of smoking with myocardial injury and clinical outcome in patients undergoing mechanical reperfusion for ST-elevation myocardial infarction. Int J Cardiovasc Imaging[Internet]. 2017[cited 2017 Nov 30];18:39-45. Available from: https://academic.oup.com/ehjcimaging/article-lookup/doi/10.1093/ehjci/jew030

26. Azhari Z, Ismail MD, Zuhdi ASM, Sari NM, Abidin IZ, Ahmad WAW. Association between body mass index and outcomes after percutaneous coronary intervention in multiethnic South East Asian population: a retrospective analysis of the Malaysian National Cardiovascular Disease Database - Percutaneous Coronary Intervention (NCVD-PCI) registry. Br Med J Open[Internet]. 2017[cited 2017 Dec 24];0:e017794. Available from: http://bmjopen.bmj.com/content/bmjopen/7/11/e017794.full.pdf

27. Numasawa Y, Kohsaka S, Miyata H, Kawamura A, Noma S, Suzuki M, et al. Impact of body mass index on in-hospital complications in patients undergoing percutaneous coronary intervention in a Japanese Real-World Multicenter Registry. PloS One[Internet]. 2015[cited 2017 Dec 24];10(4):e0124399. Available from: https:/www.ncbi.nlm.nih.gov/pmc/articles/PMC4397046/pdf/pone.0124399.pdf

28. Gallo AM, Laurenti R. Mudança de hábitos e atitudes em sobreviventes de infarto agudo do miocárdio e angioplastia primária. Saúde[Internet]. 2014[cited 2017 Dec 29];40(2):59-66. Available from: https://periodicos.ufsm.br/revistasaude/article/view/13287/pdf

29. Lima FMA, Simonetti JP. Atividade educativa com pacientes submetidos à angioplastia coronariana. Rev Enferm UFPE[Internet]. 2017[cited 2017 Dec 29];11(8):3072-8. Available from: https://periodicos.ufpe.br/revistas/revistaenfermagem/article/viewFile/110211/22117

30. Bhat FA, Changal KH, Raina H, Tramboo NA, Rather HA. Transradial versus transfemoral approach for coronary angiography and angioplasty: a prospective, randomized comparison. BMC Cardiovasc Disord[Internet]. 2017[cited 2017 Dec 25];17(23):7. Available from: https://www.ncbi.nlm.nih.gov/pmc/articles/PMC5225509 